\title{
Hospitalisation for head injury due to assault among Indigenous and non-Indigenous Australians, July 1999 - June 2005
}

\author{
Lisa M Jamieson, James E Harrison and Jesia G Berry
}

H ead injury is a leading cause of disability globally, with survivors - often suffering cognitive, mood and behavioural disorders. ${ }^{1}$ Serious head injury may have long-lasting impacts on social and emotional development, and in employment. ${ }^{2,3}$ Quality of life following severe head injury can be markedly reduced, ${ }^{4,5}$ and behavioural sequelae frequently fail to resolve over time. ${ }^{6}$ The societal cost of disability following head injury is consequently substantial: services may need to be provided for life, ${ }^{7}$ and the personal and family burden is sometimes heavy.

Injury rates among the Indigenous Australian population are generally higher than those among other Australians. For example, in 1999-2000, the rate of hospitalisation for injury was about twice as high among those identifying as Indigenous as among non-Indigenous Australians. ${ }^{8}$ Assault was the most frequent cause of hospitalisation due to injury among Indigenous Australians between 2000 and 2002, but it ranked fourth among non-Indigenous Australians. ${ }^{9}$ Assault was responsible for about $44 \%$ of injury hospitalisations among Indigenous women, compared with only $2.3 \%$ among non-Indigenous women.

There has been little documentation of head injury rates among Indigenous Australians, particularly those resulting from assault. Estimating the magnitude of this problem will allow the burden of head injuries due to assault to be compared with other preventable health problems. This comparison can then provide a basis for deciding an appropriate level of investment in prevention. ${ }^{10}$ Here, we describe rates of head injury due to assault among Indigenous and non-Indigenous Australians by age, sex and location of residence.

\section{METHODS}

Hospital separation data on patients with head injuries due to assault who received inpatient care at public and private hospitals in Queensland, Western Australia, South Australia and the Northern Territory between 1 July 1999 and 30 June 2005 were obtained from the Australian Institute of Health and Welfare's National Hospital Mor-

\section{ABSTRACT}

Objective: To describe rates of hospitalisation for head injury due to assault among Indigenous and non-Indigenous Australians.

Design, setting and participants: Secondary analysis of routinely collected hospital morbidity data for 42874 inpatients at public and private hospitals in Queensland, Western Australia, South Australia and the Northern Territory for the 6-year period 1 July 1999 - 30 June 2005.

Main outcome measures: Rates per 100000 population of head injury due to assault by Indigenous status, age, sex and location of residence.

Results: The overall rate of head injury due to assault was 60.4 per 100000 population (95\% Cl, 59.8-60.9). The rate among the Indigenous population was 854.8 per 100000 (95\% Cl, 841.0-868.9), 21 times that among the non-Indigenous population (40.7 per 100 000; $95 \% \mathrm{Cl}, 40.2-41.2)$. Most Indigenous (88\%) and non-Indigenous (83\%) victims of head injury due to assault were aged between 15 and 44 years. The peak incidence among the Indigenous population was in the 30-34-year age group, whereas that among the non-Indigenous population was in the 20-24-year age group. Indigenous females experienced 69 times the injury rate experienced by non-Indigenous females.

Conclusions: Indigenous people, particularly women, were disproportionately represented among those hospitalised for head injury due to assault. Head injury imposes a substantial burden of care on individuals and communities. Along with the costs of treating head injury, these are good reasons to strengthen efforts to prevent head injury generally, with special attention to high-risk population segments.

MJA 2008; 188: 576-579

bidity Database. The scope of the study was restricted to these four jurisdictions because assignment of "Indigenous status" has been assessed as being too incomplete elsewhere. $^{11}$

Data were coded according to the International classification of diseases, 10th revision, Australian modification (ICD-10-AM). Records were selected if the principal or any additional diagnosis fields contained an ICD-10-AM code for Injury to the head (SOOS09). Sites of injuries include the skull and brain, ear, eye, face, gum, jaw, oral cavity, palate, periocular area, scalp, temporomandibular joint area, tongue and tooth. The codes do not include burns to the head. Traumatic brain injury, as defined by the Centers for Disease Control and Prevention's case definition, ${ }^{12}$ included open wound of head, fracture of skull or facial bones, intracranial injury, crushing injury of head and other unspecified head injuries. About half of selected cases included more than one code in this range, mostly referring to different aspects of the same head injury (for example, principal diagnosis S06.4 Epidural haemorrhage, plus additional diagnosis codes S02.0 Fracture of vault of skull and S06.02 Loss of consciousness for less than 1 hour). Head injuries were defined as being due to assault if they were described by one or more external cause codes of X85-Y09 (Assault), Y35-36 (Legal intervention and operations of war), Y87.1, Y89.0 and Y89.1 (sequelae, or late effects of these). To reduce double-counting, separations were excluded if the mode of admission was inward transfer from another acute care hospital.

Demographic information available from the hospital records included age, sex, Indigenous status and residential location. "Indigenous status" was defined as an individual who identified as being Aboriginal, Torres Strait Islander or both. Patients with Indigenous status "not stated" were included as "non-Indigenous" as per recommended practice. ${ }^{11}$ Residential location was grouped using the Rural, Remote and Metropolitan Areas classification, ${ }^{13}$ an index based on statistical local areas that allocates each such area in Australia to a category based primarily on population numbers and an index of 


\begin{tabular}{|c|c|c|c|c|c|c|c|c|c|}
\hline \multirow[b]{2}{*}{ Variable } & \multicolumn{4}{|c|}{ Indigenous (I) } & \multicolumn{4}{|c|}{ Non-Indigenous (NI) } & \multirow[b]{2}{*}{$\begin{array}{l}\text { Rate } \\
\text { ratio } \\
(\mathrm{I}: \mathrm{NI})\end{array}$} \\
\hline & No. & $\begin{array}{c}\text { Rate per } \\
100000 \\
(95 \% \mathrm{Cl})\end{array}$ & $\begin{array}{l}\text { Unadjusted } \\
\text { rate ratio } \\
(95 \% \mathrm{Cl})\end{array}$ & $\begin{array}{c}\text { Adjusted } \\
\text { rate ratio } \\
(95 \% \mathrm{Cl})\end{array}$ & No. & $\begin{array}{c}\text { Rate per } \\
100000 \\
(95 \% \mathrm{Cl})\end{array}$ & $\begin{array}{l}\text { Unadjusted } \\
\text { rate ratio } \\
(95 \% \mathrm{Cl})\end{array}$ & $\begin{array}{c}\text { Adjusted } \\
\text { rate ratio } \\
(95 \% \mathrm{Cl})\end{array}$ & \\
\hline Total & 14715 & $\begin{array}{c}854.8 \\
(841.0-868.9)\end{array}$ & na & na & 28159 & $\begin{array}{c}40.7 \\
(40.2-41.2)\end{array}$ & na & na & 21.0 \\
\hline \multicolumn{10}{|c|}{ Age group (years) } \\
\hline $0-4^{\ddagger}$ & 137 & $\begin{array}{c}61.3 \\
(51.7-72.7)\end{array}$ & 1.0 & 1.0 & 290 & $\begin{array}{c}6.6 \\
(5.9-7.4)\end{array}$ & 1.0 & 1.0 & 9.3 \\
\hline $5-9$ & 48 & $\begin{array}{c}20.8 \\
(15.6-27.8)\end{array}$ & $\begin{array}{c}0.3 \\
(0.2-0.5)\end{array}$ & $\begin{array}{c}0.3 \\
(0.2-0.5)\end{array}$ & 67 & $\begin{array}{c}1.4 \\
(1.1-1.8)\end{array}$ & $\begin{array}{c}0.2 \\
(0.2-0.3)\end{array}$ & $\begin{array}{c}0.2 \\
(0.2-0.3)\end{array}$ & 14.9 \\
\hline $10-14$ & 158 & $\begin{array}{c}75.3 \\
(64.3-88.1)\end{array}$ & $\begin{array}{c}1.2 \\
(1.0-1.5)\end{array}$ & $\begin{array}{c}1.2 \\
(1.0-1.5)\end{array}$ & 474 & $\begin{array}{c}10.1 \\
(9.3-11.1)\end{array}$ & $\begin{array}{c}1.5 \\
(1.3-1.8)\end{array}$ & $\begin{array}{c}1.5 \\
(1.3-1.8)\end{array}$ & 7.5 \\
\hline $15-19$ & 1476 & $\begin{array}{c}852.4 \\
(809.7-897.3)\end{array}$ & $\begin{array}{c}13.9 \\
(11.6-16.6)\end{array}$ & $\begin{array}{c}13.9 \\
(11.6-16.6)\end{array}$ & 4560 & $\begin{array}{c}96.7 \\
(93.9-99.6)\end{array}$ & $\begin{array}{c}14.6 \\
(13.0-16.5)\end{array}$ & $\begin{array}{c}15.4 \\
(13.6-17.3)\end{array}$ & 8.8 \\
\hline $20-24$ & 2383 & $\begin{array}{c}1695.9 \\
(1628.6-1765.9)\end{array}$ & $\begin{array}{c}27.7 \\
(23.2-32.9)\end{array}$ & $\begin{array}{c}26.8 \\
(22.5-31.9)\end{array}$ & 5601 & $\begin{array}{c}117.8 \\
(114.7-121.0)\end{array}$ & $\begin{array}{c}17.8 \\
(15.8-20.1)\end{array}$ & $\begin{array}{c}19.8 \\
(17.6-22.3)\end{array}$ & 14.4 \\
\hline $25-29$ & 2720 & $\begin{array}{c}2006.1 \\
(1931.3-2083.8)\end{array}$ & $\begin{array}{c}32.7 \\
(27.5-38.9)\end{array}$ & $\begin{array}{c}31.6 \\
(26.6-37.7)\end{array}$ & 4369 & $\begin{array}{c}87.3 \\
(84.8-90.0)\end{array}$ & $\begin{array}{c}13.2 \\
(11.7-14.9)\end{array}$ & $\begin{array}{c}14.3 \\
(12.7-16.1)\end{array}$ & 23.0 \\
\hline $30-34$ & 2782 & $\begin{array}{c}2140.4 \\
(2061.4-2222.5)\end{array}$ & $\begin{array}{c}34.9 \\
(29.3-41.5)\end{array}$ & $\begin{array}{c}33.7 \\
(28.3-40.1)\end{array}$ & 3571 & $\begin{array}{c}67.7 \\
(65.5-70.0)\end{array}$ & $\begin{array}{c}10.2 \\
(9.1-11.5)\end{array}$ & $\begin{array}{c}10.9 \\
(9.6-12.3)\end{array}$ & 31.6 \\
\hline $35-39$ & 2145 & $\begin{array}{c}1884.3 \\
(1805.1-1966.9)\end{array}$ & $\begin{array}{c}30.7 \\
(25.8-36.6)\end{array}$ & $\begin{array}{c}29.5 \\
(24.8-35.2)\end{array}$ & 3065 & $\begin{array}{c}57.8 \\
(55.8-59.9)\end{array}$ & $\begin{array}{c}8.7 \\
(7.8-9.9)\end{array}$ & $\begin{array}{c}9.0 \\
(8.0-10.2)\end{array}$ & 32.6 \\
\hline $40-44$ & 1422 & $\begin{array}{c}1495.5 \\
(1419.3-1575.9)\end{array}$ & $\begin{array}{c}24.4 \\
(20.4-29.1)\end{array}$ & $\begin{array}{c}23.8 \\
(19.9-28.5)\end{array}$ & 2281 & $\begin{array}{c}45.8 \\
(43.9-47.7)\end{array}$ & $\begin{array}{c}6.9 \\
(6.1-7.8)\end{array}$ & $\begin{array}{c}6.6 \\
(5.9-7.5)\end{array}$ & 32.7 \\
\hline $45-49$ & 762 & $\begin{array}{c}1003.5 \\
(933.8-1078.4)\end{array}$ & $\begin{array}{c}16.4 \\
(13.6-19.7)\end{array}$ & $\begin{array}{c}16.0 \\
(13.3-19.2)\end{array}$ & 503 & $\begin{array}{c}30.5 \\
(29.0-32.1)\end{array}$ & $\begin{array}{c}4.6 \\
(4.1-5.2)\end{array}$ & $\begin{array}{c}4.7 \\
(4.1-5.3)\end{array}$ & 32.9 \\
\hline $50-54$ & 384 & $\begin{array}{c}663.2 \\
(599.6-733.7)\end{array}$ & $\begin{array}{c}10.8 \\
(8.9-13.2)\end{array}$ & $\begin{array}{c}10.5 \\
(8.6-12.7)\end{array}$ & 989 & $\begin{array}{c}21.4 \\
(20.1-22.8)\end{array}$ & $\begin{array}{c}3.2 \\
(2.8-3.7)\end{array}$ & $\begin{array}{c}3.3 \\
(2.9-3.7)\end{array}$ & 31.0 \\
\hline $55-59$ & 128 & $\begin{array}{c}317.5 \\
(266.4-378.3)\end{array}$ & $\begin{array}{c}5.2 \\
(4.1-6.6)\end{array}$ & $\begin{array}{c}4.9 \\
(3.9-6.3)\end{array}$ & 615 & $\begin{array}{c}16.2 \\
(15.0-17.6)\end{array}$ & $\begin{array}{c}2.5 \\
(2.1-2.8)\end{array}$ & $\begin{array}{c}2.4 \\
(2.1-2.8)\end{array}$ & 19.6 \\
\hline $60-64$ & 96 & $\begin{array}{c}340.3 \\
(278.6-415.7)\end{array}$ & $\begin{array}{c}5.6 \\
(4.3-7.2)\end{array}$ & $\begin{array}{c}5.1 \\
(3.9-6.6)\end{array}$ & 317 & $\begin{array}{c}10.5 \\
(9.4-11.8)\end{array}$ & $\begin{array}{c}1.6 \\
(1.4-1.9)\end{array}$ & $\begin{array}{c}1.6 \\
(1.3-1.8)\end{array}$ & 32.4 \\
\hline $65-69$ & 30 & $\begin{array}{c}144.0 \\
(99.5-208.6)\end{array}$ & $\begin{array}{c}2.3 \\
(1.6-3.5)\end{array}$ & $\begin{array}{c}2.1 \\
(1.4-3.2)\end{array}$ & 143 & $\begin{array}{c}5.6 \\
(4.8-6.7)\end{array}$ & $\begin{array}{c}0.9 \\
(0.7-1.0)\end{array}$ & $\begin{array}{c}0.9 \\
(0.7-1.0)\end{array}$ & 25.7 \\
\hline$\geqslant 70$ & 44 & $\begin{array}{c}71.3 \\
(51.7-98.5)\end{array}$ & $\begin{array}{c}1.2 \\
(0.8-1.7)\end{array}$ & $\begin{array}{c}1.0 \\
(0.7-1.5)\end{array}$ & 314 & $\begin{array}{c}5.0 \\
(4.4-5.6)\end{array}$ & $\begin{array}{c}0.8 \\
(0.6-0.9)\end{array}$ & $\begin{array}{c}0.9 \\
(0.7-1.0)\end{array}$ & 14.3 \\
\hline \multicolumn{10}{|l|}{ Sex } \\
\hline Male $e^{\ddagger}$ & 6540 & $\begin{array}{c}767.4 \\
(748.8-786.4)\end{array}$ & 1.0 & 1.0 & 23471 & $\begin{array}{c}67.8 \\
(67.0-68.7)\end{array}$ & 1.0 & 1.0 & 11.3 \\
\hline Female & 8175 & $\begin{array}{c}940.4 \\
(920.0-961.2)\end{array}$ & $\begin{array}{c}1.2 \\
(1.2-1.3)\end{array}$ & $\begin{array}{c}1.2 \\
(1.2-1.2)\end{array}$ & 4688 & $\begin{array}{c}13.6 \\
(13.2-14.0)\end{array}$ & $\begin{array}{c}0.2 \\
(0.2-0.2)\end{array}$ & $\begin{array}{c}0.2 \\
(0.2-0.2)\end{array}$ & 69.1 \\
\hline \multicolumn{10}{|l|}{ Location } \\
\hline Metropolitan ${ }^{\ddagger}$ & 1816 & $\begin{array}{c}214.8 \\
(205.1-224.9)\end{array}$ & 1.0 & 1.0 & 14259 & $\begin{array}{c}23.9 \\
(23.5-24.2)\end{array}$ & 1.0 & 1.0 & 9.0 \\
\hline $\begin{array}{l}\text { Rural or } \\
\text { remote }\end{array}$ & 12586 & $\begin{array}{c}1499.7 \\
(1473.7-1526.1)\end{array}$ & $\begin{array}{c}7.0 \\
(6.6-7.3)\end{array}$ & $\begin{array}{c}6.9 \\
(6.6-7.3)\end{array}$ & 13399 & $\begin{array}{c}163.2 \\
(160.5-166.0)\end{array}$ & $\begin{array}{c}6.8 \\
(6.7-7.0)\end{array}$ & $\begin{array}{c}7.2 \\
(7.0-7.4)\end{array}$ & 9.2 \\
\hline
\end{tabular}

remoteness. "Metropolitan" is defined as any capital city or other city with a population of $>100000$; "rural" areas are those with a population ranging from 10000 to 99999 ; and "remote" areas are those with a population of $<10000$. For the purposes of this study, rural and remote areas were combined.
Estimated resident population counts for all demographic strata (age, sex, Indigenous status, residential location) in the four jurisdictions as at 31 December in each year were obtained from the Australian Bureau of Statistics (ABS). Annual average rates of head injury incidence (estimated number of new hospital admissions for head injury per annum in a specified stratum divided by the estimated resident population of the same stratum, multiplied by 100 000) and incident rate ratios were calculated along with 95\% confidence intervals using a generalised Poisson regression model. ${ }^{14}$ Results 


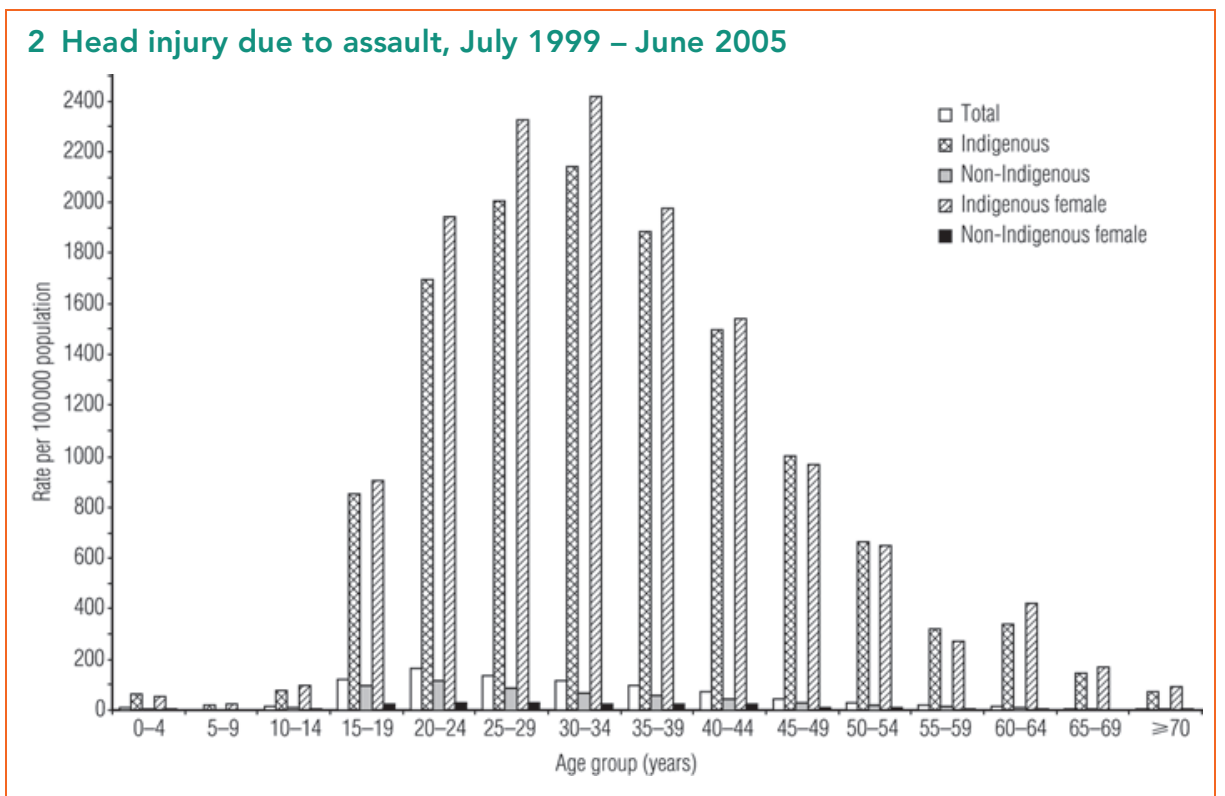

from the Poisson regression model are presented as unadjusted and adjusted incident rate ratios to estimate the independent effect of each covariate on the rate of head injury due to assault. Data were analysed using Intercooled Stata 8.0 software (StataCorp, College Station, Tex, USA).

\section{RESULTS}

There were a total of 42874 patients hospitalised for head injury due to assault during the 6-year period 1 July 1999 to 30 June 2005 in the four Australian jurisdictions included in our study. Rates were markedly higher among the Indigenous population (Box 1). The rate of head injury due to assault among non-Indigenous people rose in early adulthood, peaked at ages 20-24 years and declined thereafter. On the other hand, the rate among Indigenous people rose in early adulthood, peaked at ages 30-34 years and remained elevated through middle age. Most Indigenous (88\%) and non-Indigenous (83\%) victims of head injury due to assault were aged between 15 and 44 years (Box 1, Box 2).

The rate of head injury due to assault in the total population was 60.4 per 100000 (95\% CI, 59.8-60.9). Among the Indigenous population it was 854.8 per 100000 , while among the non-Indigenous population it was 40.7 per 100000 , giving a rate ratio of 21.0 (Box 1). The Indigenous to non-Indigenous rate ratios ranged from 23 to 33 among the 25-29-year to 45-49-year age groups. The rate ratio was especially high among females: 69.1 at all ages and 93.3 at 30-34 years. Indigenous people living in both metropolitan and rural/remote locations experienced nine times the rate experienced by non-Indigenous people.

Indigenous females experienced greater rates of head injury due to assault than Indigenous males, and the rate among Indigenous people living in rural/remote locations was seven times the rate among those living in cities. The rate among nonIndigenous females was around one-fifth that of non-Indigenous males; but, as in the Indigenous population, the rate among nonIndigenous people living in rural/remote locations was seven times the rate among those living in cities.

\section{DISCUSSION}

Our findings indicate that the rate of hospitalisation for head injury due to assault among Indigenous Australians in four jurisdictions was 21 times that among non-Indigenous Australians in the 6-year period 1 July 1999 to 30 June 2005 after adjustment for differences in age, sex and residential location. Indigenous people had higher rates in every age group; the excess morbidity was greatest at 30-34 years, and the ratio of Indigenous to non-Indigenous rates was largest at 35-49 years. Indigenous females experienced 69 times the rate of head injury due to assault experienced by non-Indigenous females. The excess of head injury due to assault among the Indigenous population has an age distribution (15-49 years) similar to that of the excess of all causes of mortality in this population. ${ }^{15}$ That is, this condition has its greatest impact upon people upon whom communities depend for parenting, income and other activities.

An earlier study of hospitalisations for injury among Indigenous people noted that, according to ABS census data, about twofifths of Indigenous people live in New South Wales, Victoria, the Australian Capital Territory and Tasmania, the four jurisdictions for which "Indigenous status" enumeration is considered to be of insufficient quality to warrant reporting. ${ }^{9}$ In their study period (1 July 2000 to 30 June 2002), almost a quarter of all external cause separations recorded for Indigenous people involved residents of these jurisdictions. While the excluded jurisdictions represent a sizeable proportion of the Indigenous population of Australia, their inclusion would reduce the reliability of our findings, and we do not think it advisable to generalise our findings to them.

The finding that Indigenous people had much higher rates of head injury due to assault than non-Indigenous people is consistent with reports in other developed countries with indigenous populations. ${ }^{16}$ The high rates in our study imply a substantial personal and social burden on injured people, their families and their communities, and a financial burden on already stretched health systems. ${ }^{17}$ However, the most serious cost is arguably the stressing and disruption of social bonds among Indigenous Australians as a result of such trauma.

It has been suggested that the rate and types of violence among Indigenous Australians are increasing, with much of the aggression being directed towards women. ${ }^{18}$ The "Little children are sacred" report states that the role of alcohol in violence among Indigenous communities cannot be emphasised enough, and suggests that aggression is greater in communities where alcohol is easily obtained. ${ }^{19}$ The complex social history of Indigenous Australians needs to be carefully considered if alcohol-related violence is to be comprehensively explained. It has been asserted that the inferior health status of Indigenous Australians is inextricably linked to their historical legacy, their ongoing social and economic disadvantage (including displacement from their homes, land and lifestyle) and psychosocial trauma (particularly in regard to child separation). ${ }^{20}$

Non-urban place of residence was a risk factor for hospitalisation for head injury due to assault among both Indigenous and nonIndigenous Australians. Retrieval and transport of patients with head injury to designated trauma centres may be difficult for 
those living in rural or remote locations. ${ }^{21}$ Although services to manage the consequences of assault are essential, primary prevention is at least as important.

Priority areas of action to reduce the prevalence of head injury due to assault among Indigenous Australians that are supported by the National Public Health Partnership ${ }^{22}$ include:

- collaborating with key agencies responsible for services and planning among Indigenous groups to ensure that prevention of head injury due to assault is integral to policy development;

- raising awareness of the challenges of program implementation among Indigenous populations, particularly when populations are small and dispersed; and

- supporting safety promotion and injury prevention policies that address a range of social, environmental and behavioural factors and provide good examples of dealing with the underlying alienation and disadvantage of Indigenous people.

The associated National Aboriginal and Torres Strait Islander Safety Promotion Strategy $^{23}$ takes a broad approach emphasising the diverse determinants of safety. However, before true parity between Indigenous and non-Indigenous victims of head injury due to assault is reached, fundamental shifts in the political and societal paradigms that determine Indigenous social capital may also be necessary.

\section{ACKNOWLEDGEMENTS}

The results and interpretations presented here are those of the authors and not the Australian Institute of Health and Welfare.

\section{COMPETING INTERESTS}

None identified.

\section{AUTHOR DETAILS}

Lisa M Jamieson, PhD, Research Fellow ${ }^{1}$ James E Harrison, MB BS, MPH, Director ${ }^{2}$ Jesia G Berry, BHSc(Hons), GDPH, Research Officer $^{2}$

1 School of Dentistry, University of Adelaide, Adelaide, SA.

2 Research Centre for Injury Studies, Flinders University, Adelaide, SA.

Correspondence:

lisa.jamieson@adelaide.edu.au

\section{REFERENCES}

1 Peden M, McGee K, Krug E, eds. Injury: a leading cause of the burden of disease, 2000. Geneva: World Health Organization, 2002.

2 Max JE, Koele SL, Castillo CC, et al. Personality change problem in children and adolescents following traumatic brain injury. J Int Neuropsychol Soc 2000; 6: 279-289.

3 Ryb GE, Soderstrom CA, Kufera JA, Dischinger P. Longitudinal study of suicide after traumatic injury. J Trauma 2006; 61: 799-804.

4 Kiely JM, Brasel KJ, Weidner KL, et al. Predicting quality of life six months after traumatic injury. J Trauma 2006; 61: 791-798.

5 Davey TM, Aitken LM, Kassulke D, et al. Longterm outcomes of seriously injured children: a study using the Child Health Questionnaire. J Paediatr Child Health 2005; 41: 278-283.

6 Schwartz L, Taylor HG, Drotar D, et al. Long-term behavior problems following pediatric traumatic brain injury: prevalence, predictors, and correlates. J Pediatr Psychol 2003; 28: 251-263.

7 Turner-Stokes L. The national service framework for long term conditions: a novel approach for a "new style" NSF. J Neurol Neurosurg Psychiatry 2005; 76: 901-902.

8 Lehoczky S, Isaacs J, Grayson N, Hargreaves J. Hospital statistics. Aboriginal and Torres Strait Islander Australians 1999-2000. Occasional paper. Canberra: Australian Bureau of Statistics and Australian Institute of Health and Welfare, 2002. (ABS Cat. No. 4711.0.)

9 Helps YLM, Harrison JE. Hospitalised injury of Australia's Aboriginal and Torres Strait Islander people 2000-02. Injury Technical Paper Series No. 8. Adelaide: Australian Institute of Health and Welfare, 2006. (AIHW Cat. No. INJCAT 94.)
10 Corso P, Finkelstein E, Miller T, et al. Incidence and lifetime costs of injuries in the United States. Inj Prev 2006; 12: 212-218.

11 Australian Institute of Health and Welfare. Improving the quality of Indigenous identification in hospital separations data. Canberra: AlHW, 2005. (AIHW Cat. No. HSE 101.)

12 Thurman DJ, Sniezek JE, Johnson D, et al. Guidelines for surveillance of central nervous system injury. Atlanta: Centers for Disease Control and Prevention, 1995

13 Australian Institute of Health and Welfare. Rural, regional and remote health: a guide to remoteness classifications. Canberra: AlHW, 2004. (AlHW Cat. No. PHE 53.)

14 Rothman K, Greenland S. Modern epidemiology, 2nd ed. Philadelphia: Lippincott, Williams and Wilkins, 1998

15 Cunningham J, Condon JR. Premature mortality in aboriginal adults in the Northern Territory, 1979-1991. Med J Aust 1996; 165: 309-312.

16 Langlois JA, Rutland-Brown W, Thomas KE. The incidence of traumatic brain injury among children in the United States: differences by race. $J$ Head Trauma Rehabil 2005; 20: 229-238.

17 Moncrieff NJ, Qureshi C, Deva AK. A comparative cost analysis of maxillofacial trauma in Australia. J Craniofac Surg 2004; 15: 686-691.

18 Memmott P, Stacy R, Chambers C, Keys C. Violence in Indigenous Communities. Report to Crime Prevention Branch of the Attorney-General's Department. Canberra: Attorney-General's Department, 2001.

19 Wild R, Anderson P. Ampe akelyernemane meke mekarle: "little children are sacred". Report of the Northern Territory Board of Inquiry into the Protection of Aboriginal Children from Sexual Abuse. Darwin: NT Government, 2007.

20 Mclntyre PB, Menzies RI. Immunisation: reducing health inequality for Indigenous Australians [editorial]. Med J Aust 2005; 182: 207-208.

21 Gruen RL, Bailie RS, Wang Z, et al. Specialist outreach to isolated and disadvantaged communities: a population-based study. Lancet 2006; 368: 130-138.

22 National Public Health Partnership. The National Injury Prevention and Safety Promotion Plan 2004-2014. Canberra: NPHP, 2004.

23 National Public Health Partnership. The National Aboriginal and Torres Strait Islander Safety Promotion Strategy. Canberra: NPHP, 2004.

(Received 28 Nov 2007 accepted 20 Mar 2008) 